\title{
CORE HOUSING STRATEGY FOR IMPROVED URBAN LOW-COST PUBLIC HOUSING DELIVERY IN ANAMBRA STATE, NIGERIA
}

\author{
Dr. Nnaemeka Bennet Christian Dillon Okoye ${ }^{1}$, \\ Dr. Anthony Dornubari Enwin ${ }^{2}$ and Dr. Ifeanyi C. Nelson Anyanechi ${ }^{3}$ \\ ${ }^{1}$ Department of Architecture, School of Environmental Design and Technology, Federal \\ Polytechnic Oko, Nigeria. E-mail: emii2him@gmail.com \\ ${ }^{2}$ Department of Architecture, Faculty of Environmental Sciences, Rivers State University, \\ Port Harcourt. E-mail: anthonyenwin@gmail.com \\ ${ }^{3}$ Department of Building Technology, School of Environmental Design and Technology, \\ Federal Polytechnic Oko, Nigeria. E-mail: ifeanyianyanechi@gmail.com
}

Cite this article:

Okoye N.B.C.D., Enwin A.D., Anyanechi I.C.N. (2022), Core Housing Strategy for Improved Urban Low-Cost Public Housing Delivery in Anambra State, Nigeria. African Journal of Economics and Sustainable Development 5(1), 1-16. DOI: 10.52589/AJESDBHUZFSCK.

\section{Manuscript History}

Received: 4 Dec 2021

Accepted: 29 Dec 2021

Published: 11 Jan 2022

Copyright $\odot 2020$ The Author(s). This is an Open Access article distributed under the terms of Creative Commons Attribution-NonCommercialNoDerivatives 4.0 International (CC BY-NC-ND 4.0), which permits anyone to share, use, reproduce and redistribute in any medium, provided the original author and source are credited.
ABSTRACT: Anambra state of Nigeria experiences acute housing shortage for urban low-income population owing to inefficient public housing delivery system principled on conventional full-provision house types. Insufficiency of funds for housing development is a major cause. Increased rate and scale of housing production and volume of housing stock have been stalled. Low-income households are adversely affected, being priced out of the limited stock. Core housing, a partial-provision strategy believed to require less financial resources has been neglected. This research focused on the potentials of core housing strategy in financial cost-saving and other aspects of public housing products' performance. Components of public housing products' performance and the measuring variables were first outlined; followed by a review of the relationship between core housing and the variables, which was apt and revealing. This study has widened knowledge and prepared grounds for empirical studies of core housing performance in Anambra State public housing sector.

KEYWORDS: Public Housing; Efficient Public Housing; Products' Performance; Core Housing Delivery; Financial CostSaving 


\section{INTRODUCTION}

Housing problems have persistently attracted noticeable attention in global housing discussions. This is not surprising judging from the great impact of this phenomenon on the socio-economic well-being of any nation. Expectedly, the developing countries of the world are mostly affected by the lack of adequate housing supply. Particularly disadvantaged are the low-income populations who hardly have the financial muscle to compete for the limited housing stock available; due to their lean financial status. Nigeria, a developing Africa country, is facing challenges in meeting up with production of housing units for the increasing urban population, particularly the low-income. World Bank (2018) observes that demand for affordable housing in Nigeria is large and growing, with a sizable deficit of 17 million units and a growth rate of 20 percent annually. According to the study, the output in the formal housing sector is not more than an annual figure of 200,000 housing units and covers only a fraction of a minimum of 700,000 units required. It further remarks that the majority of houses produced in Nigeria cater for the upper income households, leaving an acute housing shortage for middle and lower income ones.

Remarkably, Anambra State of Nigeria is reported to be facing housing shortage in the urban areas, the people mostly affected being low-income households. As Ugonabo and Emoh (2013) observe, the unpleasant picture and deplorable condition of housing in Nigeria applies equally to Anambra State, if not to a higher extent considering that more than $60 \%$ of the state's population live in urban areas. One of the most crucial challenges facing Anambra State, the study asserts, is the provision of adequate units of affordable housing, particularly for the low-income people. Public housing production based on the current delivery system has been observed to be inefficient. The system of housing production in vogue is principled on the development of full-provision/finished (whole) house types. Unit cost of housing production is observed to be high such that the scale of housing production desired is not achieved. How then can the scale of housing production be increased in order to make more housing units available in the volume of housing stock for the low-income urban dwellers?

In the opinion of Atamewan and Olagunju (2017) a housing strategy known as core housing (incremental housing) that allows households to develop housing in several stages while in residence is key to reducing homelessness, and enhancing housing sustainability for households of low earnings. In support of this assertion, Napier (2002) reckons that African countries such as Kenya, Sudan, South Africa and Ghana, and others across the globe (including Chile, Mexico, Brazil, Thailand, Turkey, Indonesia, and El-Salvador) have used this strategy to improve their housing delivery. Irouke, et al., (2017) equally report that the Federal Government of Nigeria, between 1979 and 1983, utilized the core housing strategy for the provision of low-cost housing across the nation. Ogun State in Nigeria has utilized this strategy for the development of public housing programmes.

Surprisingly, the Anambra State government has only stopped at the initial attempts made at this initiative in developing public housing. In these endeavours the government through its agencies developed and sold few core houses to citizens. In other cases some serviced lands were sold to beneficiaries who were to develop according to the government approved designs. Although these endeavours produced some core housing units, it appears that the core housing strategy has been neglected in public housing provision in Anambra State. Judging that the public housing delivery strategy in question has worked elsewhere and has been utilized in alleviating urban low-income housing problems, it is pertinent to reconsider 
its implementation in Anambra State. Pertinent to note also is the assertion of Beattie, et al., (2010) that core housing (incremental housing) is producing efficient and successful performance in housing provision in a wide range of contents and locations around the world. The study presents this method as a universal strategy that has proven ability to meet current and future challenges throughout the developing world.

On this note and in order to widen knowledge on this area of study, this research first outlines the variables for measuring various components of public housing products' performance. It further reviews the potentials and contributions of the core housing strategy in financial costsaving for increased rate and scale of housing production (and volume of housing stock), and other components of public housing products' performance. This is in order to know how it functions not only in saving cost and accelerating housing production rate/scale and volume of housing stock, but also in the discharge of other aspects of efficient public housing delivery. It is necessary to know this in order to ascertain that its operations will not be in jeopardy with other aspects of public housing products' performance, apart from financial cost-saving and increase in housing stock. This is in a bid to set the pace for empirical studies on the performance of core housing in Anambra State and to know if it could be recommended for adoption for urban low-cost housing provision.

\section{MEANING OF CORE HOUSING}

Core housing delivery strategy is a low-cost housing process conceived in answer to the limitations of households who are unable to afford the full-provision/finished (whole) houses developed via the conventional public housing system, due to their lean financial dispositions. It is driven by the provision of a minimal house known as the core house or starter house (shelter). Historically, according to Abrams (1964), a core house is a structure that is professionally designed to be somewhat incomplete initially and most importantly to be minimal in size or level of completion, with the intention that families incrementally add space to or sub-divide it after occupation. The study views core housing as a structure minimal in size and somewhat partially complete initially, which residents incrementally expand, in response to their evolving needs and economic ability. According to the study, core housing schemes are meant to be located outside the city (the city fringes) where land is cheaper and not within the city, and are instrumental to city expansion.

In the view of Pandelaki and Shiozaki (2010), a core house is a small unit or permanent structure that is incomplete at first, with minimum livable space and facilities designed to be upgraded over time. The house can also have minimal levels of finishes or services which are designed to be upgraded over time. The study equally observes that core housing is meant to be a flexible and affordable way in which families can own their houses gradually, if they lack the financial ability to acquire them instantly. Essentially, young families can start with occupying a minimal house (core house) and expand them as the family size increases. The study equally notes that core housing is used for city expansion being ideally located in the suburbs. Maly and Tamyo (2012) explain the core house as an initial habitable but minimal (low-cost) structure which households add on to while living there. Goethert (2010) notes that core houses begin as starter core shelters, in the form of multi-purpose rooms (studio apartments), with basic kitchen/bath facilities adding that the owners are expected to control the expansion based on their needs and resources. The understanding is that though the whole 
house type is better placed to cater for the household's space need, in core housing only the basic is meanwhile provided in order to bring down the cost of the initial habitable unit. The cost of house expansion is then conveniently spread over a period of time through incremental development. The provision of core houses is therefore meant as an alternative to the whole or full-provision/finished houses on grounds of affordability.

\section{SHORTCOMINGS OF CONVENTIONAL FULL-PROVISION/FINISHED (WHOLE) PUBLIC HOUSING SYSTEM AND EMERGENCE OF CORE HOUSING STRATEGY}

The conventional system of public housing delivery through the full-provision method of finished houses (whole houses) is greatly confronted with financial difficulty in execution (Napier, 2002). This is because the available financial resources for public housing are hardly sufficient to provide large-scale full-provision housing for the low-income people. Napier (2002), in consideration of this, posits that it is the shortcomings of the conventional public housing system in performance, particularly in provision of affordable housing for the lowincome households that led to the conception of the core housing strategy. According to the study, an investigation of the roots of the core housing (partial-provision) concept reveals that it was essentially a compromise which allowed governments to pull back from the provision of completed (full-provision/finished) mass housing because of the huge financial demands involved. Abrams (1964) equally observe that this mode of construction (core housing) which provides partially-completed housing units was interpreted to be as a result of lack of sufficient funds to build whole (full-provision/finished) houses by government, or insufficient personal savings or appropriate financial assistance by individuals to acquire them even if built. Core housing therefore arose out of an acknowledgement not only that governments could not afford the development of whole houses (full/finished provision) but also that most households could also not afford it. As would be explained in the section on "financial costsaving" this strategy contributes to the increase of rate and scale of housing production which leads to increase of housing stock.

\section{CORE HOUSING AND COMPONENTS OF PUBLIC HOUSING PRODUCTS' PERFORMANCE}

This study is concerned with effort in literature search to know if core housing as a public housing delivery strategy has the potential for financial cost-saving, which could lead to increasing the rate and scale of housing production and low-cost housing stock. It also considers how this housing strategy performs in promoting other aspects of public housing products' performance. This is in order to be sure that apart from the possibility of having the potential for increasing public low-cost housing stock; its operation will not jeopardize other key components of efficient public housing products' performance. In setting the background for discussion on core housing strategy and these components, brief notes on public housing delivery and efficiency of public housing delivery are apt and are rendered below. 


\section{Public Housing}

In spite of the different meanings and connotations of public housing in literature, there is a consensus among authors and researchers that the goal of public housing in most countries of the world is the provision of subsidized housing to households, who are unable to gain access to decent housing at market prices (Balchin, Isaac \& Chen, 2000; Liu, 2007; Ibem, et al., 2011). Kolli and Putta (2014) agree to this stating that the purpose of public housing is to assist those who cannot compete in a marketplace to own or have access to decent housing. According to Mukhtar and Amirudin (2016) equally, the purpose of public housing projects is to assist low income earners who cannot compete on a market place to own or have access to decent housing. Public housing has therefore been simply described as government-provided or subsidized housing project(s) whose objective is to make decent housing available for households who cannot access it at market conditions and prices. Generally, it stands for effort put in place to realize the provision of housing for households who by their economic status are not able to gain access to decent housing at market prices.

\section{Efficiency of Public Housing Products' Performance.}

Efficiency is regarded as the extent to which a resource is used for the intended purpose. It is equally considered as thorough or careful use of resources to produce the desired effect. Efficiency of public housing products' performance speaks of putting some measures in place in order to make public housing products work better or achieve desired goals. This connotes public housing delivery being processed to a better position for the achievement of its purpose. Mukhtar and Amirudin (2016) opine that if the purpose of a public housing project is not achieved, it is then regarded as unsuccessful, in other words inefficient. Put together, efficiency of public housing products involves the provision of necessary amenities to make government housing delivery available for those households who cannot access it at market conditions and prices functional, convenient, aesthetically pleasing, safe and hygienic (Ibimilua \& Ibitoye, 2015). According to Ibimilua and Ibitoye (2015), the quality of public housing is considered in terms of the physical appearance of the building (aesthetics), facilities provided (services), condition of walls and roof and other structural components (functionality), and the environmental conditions of the buildings.

\section{Components of Public Housing Products' Performance}

Public housing in this study is viewed in terms of what the delivery system applied is able to accomplish in order to make adequate and acceptable housing available for the low-income urban households. In other words the capability of the housing projects achieved via the operative housing strategy to improve housing quantitatively as well as qualitatively. Having this background, a view of public housing delivery from the housing projects perspective brings the contribution of Mukhtar and Amirudin (2016) into relevance. The study classifies the criteria for measuring the success (efficiency) of housing projects into two broad areas. These areas are: (i) project management performance and (ii) final product performance. The concern of this study on how core housing as a product affects the performance of public housing delivery; whether it performs efficiently or not? It is therefore related to the second category stated, which is final product performance. 
Mukhtar and Amirudin (2016), in specifying criteria for measuring housing products' performance reveal four conditions. The four conditions stated in the criteria by Mukhtar and Amirudin (2016) for measuring the performance of the final product of housing projects are:

(a) meeting the project's purpose;

(b) end users' satisfaction;

(c) environmental impact; and

(a) aesthetic appearance

The study (Mukhtar \& Amirudin, 2016) opines that for public housing to be successful, the housing must be affordable for low-income earners and allocated to people based on needs. It emphasizes that the end users' satisfaction is vital to the success of the final product, being the people who occupy the housing. Therefore, housing should be designed and constructed in such a way that will give the end-users maximum satisfaction. The study reckons that the environmental quality and its sustainability to the needs of people of the area are very essential, noting that public housing should not have a detrimental effect on the community or environment. Aesthetic appearance of the housing units is equally seen as a principal measure of public housing product success, as Mukhtar and Amirudin (2016) is of the opinion that appealing appearance of housing preserves respect to the occupants and increases acceptability of the projects by the end users. According to the study, proper handling of these criteria will go a long way to improve the performance of the final product of public housing projects in Nigeria.

The criteria by Mukhtar and Amirudin (2016) for measuring the performance of the final product of public housing projects are further illustrated in the following model.

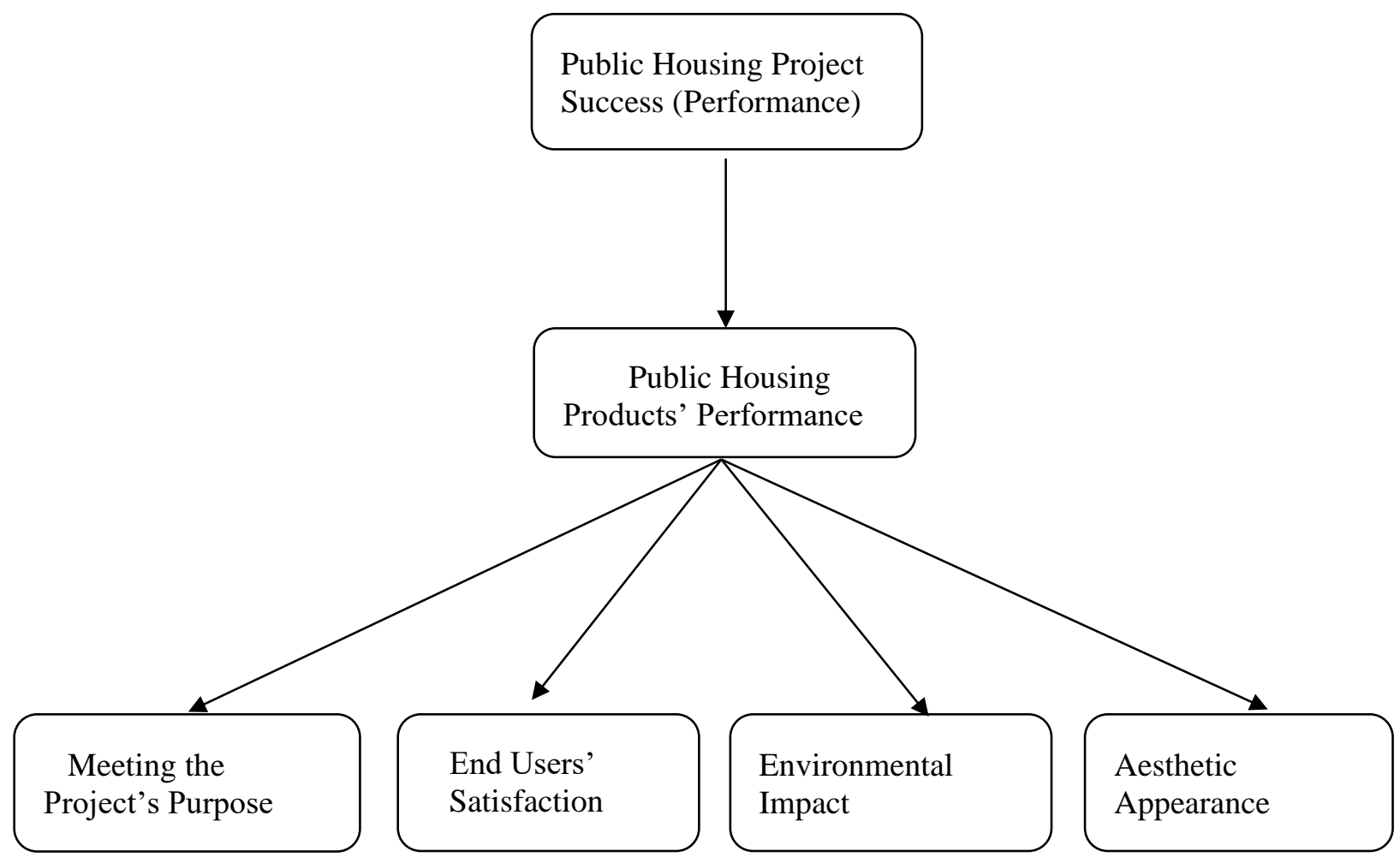

Source: Author's fieldwork (2017); adapted from Mukhtar and Amirudin (2016). 
These conditions agree with the earlier-stated view of Ibimilua and Ibitoye (2015) on the implications of efficient public housing products' performance as being able to provide: (i) functional; (ii) convenient; (iii) aesthetically pleasing; (iv) safe; and (v) hygienic housing and environment. The study further opines that the quality (performance) of public housing is considered in terms of the physical appearance of the building, facilities provided, condition of walls and roof and other structural components, and the environmental conditions of the buildings. Furthermore, they relate to the opinion of Kolli and Putta (2014) that the performance of public housing products is significantly determined by: (i) quality of dwelling units, efficiency of the basic amenities; and quality of the built environment. Relating the observations of Ibimilua and Ibitoye (2015) and Kolli and Putta (2014) with that of Mukhtar and Amirudin (2016) therefore, the criteria for measuring the performance of the final product of public housing projects can be considered to principally imply the following:

(i) financial cost-saving (affordability for end-users, meeting the project's purpose, end-users' satisfaction - Mukhtar and Amirudin, 2016)

(ii) design functionality (functional, convenient, safe, hygienic, condition of walls and roof and other structural components - Ibimilua and Ibitoye, 2015; quality of dwelling units, efficiency of the basic amenities - Kolli and Putta (2014); meeting the project's purpose, end-users' satisfaction - Mukhtar and Amirudin, 2016)

(iii) environmental impact relief (hygienic housing and environment, environmental conditions of the buildings - Ibimilua and Ibitoye (2015); quality of the built environment - Kolli and Putta (2014); environmental impact- Mukhtar and Amirudin, 2016);

(iv) aesthetic appeal (aesthetically pleasing, physical appearance of the building - Ibimilua and Ibitoye, 2015; aesthetic appearance - Mukhtar and Amirudin, 2016); quality of dwelling units, quality of the built environment - Kolli and Putta (2014); and

(v) services functionality (functional, convenient, hygienic, facilities provided - Ibimilua and Ibitoye, 2015; quality of dwelling units, efficiency of the basic amenities - Kolli and Putta (2014); meeting the project's purpose, end users' satisfaction - Mukhtar and Amirudin, 2016)

On this basis therefore, this study situates the criteria for measuring the performance of the final product of public housing projects as comprising of the under-listed elements, derived from Kolli and Putta (2014), Ibimilua and Ibitoye (2015) and Mukhtar and Amirudin (2016) as earlier reviewed. These elements are: (i) financial cost-saving; (ii) design functionality; (iii) environmental impact reduction; (iv) aesthetic appeal; and (v) services functionality. This is further illustrated in the following model. 


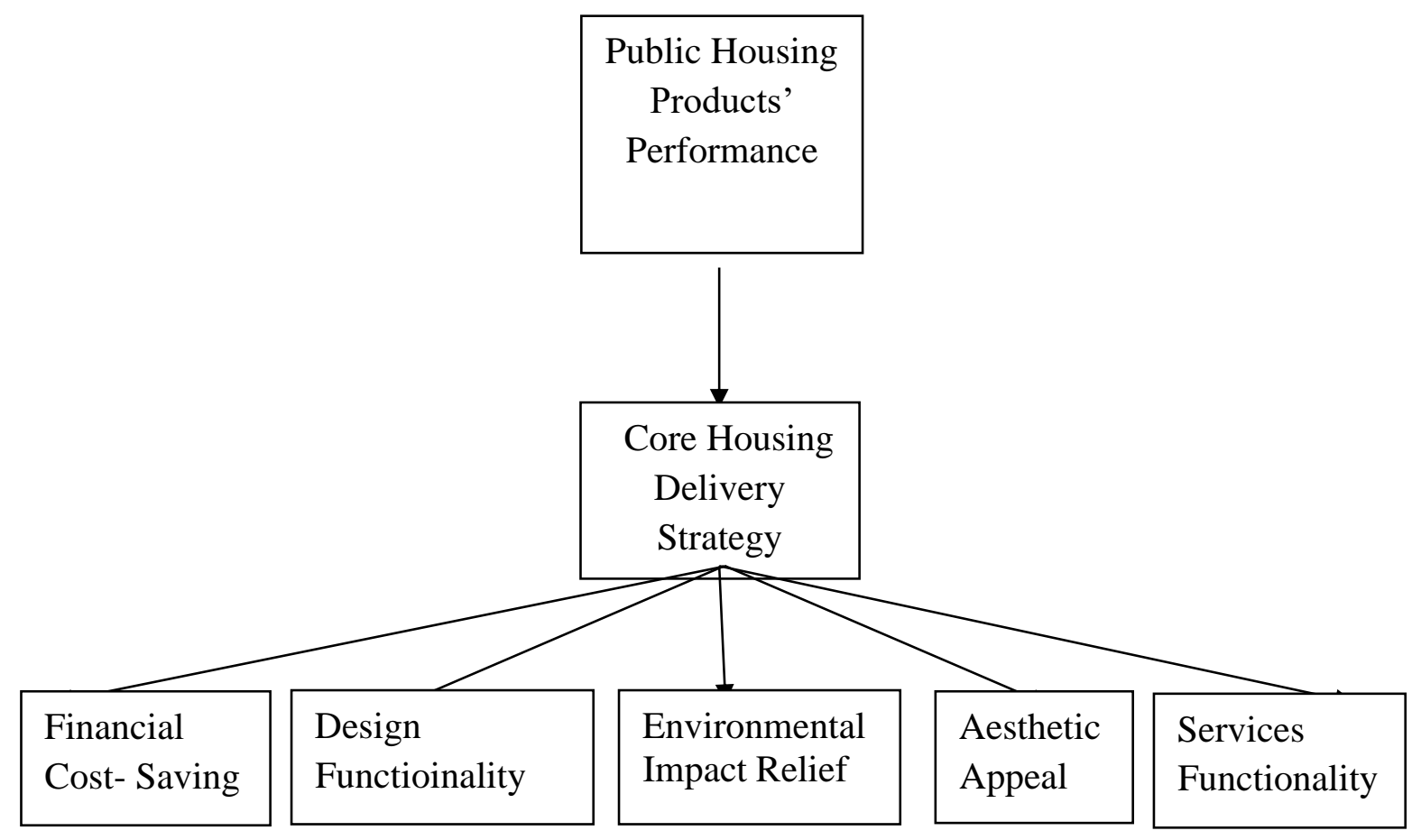

Source: Author's fieldwork (2017)

In view of this model presentation therefore, this study in considering the possible application of core housing strategy to improve the urban low-income public housing stock, views the preceding elements as important components of performance of public housing products. It discusses how the practice of core housing strategy could affect public housing products performance through these components, namely: (i) financial cost-saving; (ii) design functionality; (iii) environmental impact reduction; (iv) aesthetic appeal; and (v) services functionality.

\section{Core Housing Strategy and Financial Cost-Saving}

One of the major influences of financial cost of public housing projects is in the type of housing delivery strategy adopted. The financial cost can be controlled and lowered if the adopted strategy operates with the ability to do so. As such, the importance of proper choice of a financial cost-saving delivery strategy cannot be over-emphasized. Hence, researchers have called for the application of cost-reducing housing delivery strategies and architectural designs for housing projects (Ajanlekoko, 2001). This is because they play vital roles in determining eventual house price, in view of their influences on building and project costs. According to Ajanlekoko (2001) the catalogue of building (architectural) design variables, which have great impact on house price and project cost are controlled by the architectural design process. Architectural design process itself derives from the type of housing delivery strategy in operation. The study notes that parameters such as building size and shape and building materials specification (building material types, finishes) which greatly influence house price are determined at the design level. In the light of this, financial cost-saving in 
housing design can be determined by the variables: (i) building size; (ii) building shape; and (iii) building materials specification.

Ibem, et al., (2015) equally opine that financial cost-saving in housing design is related to: (i) initial cost of housing; and (ii) cost over time. It therefore implies that if the proper control of architectural design variables is not executed at the design stage, house types that are expensive to develop often result. This reality amplifies the importance of applying financial cost-saving housing strategies that would avail cost-saving house designs in implementation of housing policies. Buckley and Kalarickal (2005) and Waibel, et al., (2007) are of the opinion that housing units have to be designed and constructed in a way that the people they are meant for can afford them, hence inculcating financial cost-saving measures. Atamewan and Olagunju (2017) express the view that the house type suitable for and acceptable to urban dwellers who earn low incomes is that whose design is not expensive to build or maintain.

Core housing strategy has been reckoned to have the potential for achieving financial costsaving designs for affordable low-cost housing provision in a phased manner. According to Maly and Tamyo (2012), the principle of core housing, which provides an initial minimal livable space, is considered a cost-efficient type of housing. Improvement of affordability of housing using the core housing strategy can be achieved by the implementation of pertinent architectural design measures or characteristics which are instrumental to reduced housing price. The potential for financial cost-saving of core housing strategy is enhanced by the allowance of spread of building cost over years, which makes it possible to bring down the initial price of the habitable unit (Kamau, 2002). The study stressed that though this may not make this house type cheaper in the long run, it contributes to affordability as the households may not be able to access capital guarantees to buy a house or secure mortgage finance.

Napier (2002) observes that if core houses are well designed, sited and constructed appropriately the residents would find it relatively simple to add space and thus financial cost-saving is achieved through the cost spread in relation to the income available. Similarly, Ibem, et al., (2015) view core housing strategy as a cost-efficient approach in public housing, noting that their provision contributed positively to the affordability of the housing programmes studied. Notably, economy plays an important and positive role in the core housing concept and its design being the main goal of this housing approach. According to Maly and Tamyo (2012), because the initial cost of constructing a core house is comparatively low, the choice of this form of house type leads to increase in housing production scale and stock and invariably allows for housing provision for an increased number of households. As a result of the observed financial cost-saving advantage of core housing by these studies they opine that the strategy can be used to reduce gaps in public housing provision by increasing the rate and scale of production of habitable units which leads to an increase of available housing stock.

Derived from the preceding review, the criteria for measuring core housing for financial costsaving in public housing delivery are:

(i) building size;

(ii) building shape;

(iii) building materials and finishes specification. 
(iv) initial cost of house; and

(v) house cost over time

\section{Core Housing and Design Functionality}

Essentially, design is a relationship between users with problems to be solved and designers with solutions to offer. In doing this, a clear understanding of the functional requirements of a building project is essential towards realizing its success or efficient performance. This is because the intention to develop a building project is derived from a need, a purpose or mission, and a desired result. As such its design should be done in a way that reflects these factors. Knowledge of this fact therefore underscores the importance of design functionality in the achievement of an efficient public housing delivery. Generally, the design of a project is deemed to be functionally efficient or successful if it is able to meet up with the emotional, cognitive, and cultural needs of the end-users as well as the technical requirements of the activities it houses.

Core housing approach has to be observed to satisfy design functionality in the public housing system, Nigeria, by providing accommodation that is: (i) qualitative; (ii) adequate; and (iii) satisfying. Buildings that are functionally successful create a safe, productive and livable environment, hence contributing to the overall efficiency of the housing delivery system. Ibem, et al., (2015) consider functionally efficient (sustainable) public housing as having to do with: (i) adequate security (clear demarcation of spaces using walls, limited number of external doors); (ii) lighting and ventilation; and (iii) thermal comfort. A building can be said to be functionally efficient when the minimum necessary space for the desired functions are properly accommodated, with no or minimum space wastage. From this point of view, design functionality of a housing system could be regarded as: (i) satisfaction of minimum space requirements; and (ii) minimizing space wastages. In doing this, it involves flexibility in space use and adaptability for expansion in the architectural design concept. These are described as decisions at the inception of project design to incorporate elements and concepts that will assist with multiple uses of available spaces at inception (flexibility in space use), and adaptations for future uses and expansion (adaptability for expansion). Okoye, et al., (2021) opine that flexible spaces authenticate the functionality of the core housing unit in performance of dual or multi-purpose activities. From this viewpoint, we see design functionality of a housing system as involving: (i) design flexibility in present use; and (ii) adaptability for future use and expansion.

The main goal or target of a design is to produce something that is fit for purpose (functional), and at the same time agreeable to the potential clients (Chipambwa \& Muzenda, 2017). We design things in a way that they can perform certain tasks (functions) for us, meaning they are functional. A good design is therefore functionally sound and aesthetically satisfying, presenting a unified and harmonious appearance. In other words, a good building design does not just appear or feel nice but works. It should not allow the users sweat out trying to figure out how it functions. Furthermore, Zurko (1957) opines that design functionality holds the basic premise in architecture that form should follow function, which connotes that form is derived from function. The study (Zurko, 1957) equally believes there is evidence from the history of architecture that at different times and places architects had either used the function of the building as a framework, or had unconsciously followed the idea of close relationship of form to function, in constructing a design. Routio (2007) traced 
the Functionalism Theory of Fitness to Purpose, which is a theory that architects should design buildings based on their purposes, back to the Vitruvian triad and continued to the works of Louis Sullivan, Ottor Wagnar and later Frank L. Wright who greatly influenced this theory. Design functionality therefore becomes a guiding principle for the designer and a standard with which to measure architecture.

Design functionality within the context of this study can be summarized to reflect the following:

(i) satisfaction of end-users' needs;

(ii) satisfaction of technical requirements;

(iii) satisfaction of minimum space requirements;

(iv) minimizing of space wastages;

(v) adequate security;

(vi) proper lighting and ventilation;

(vii) thermal comfort;

(viii)design flexibility in initial space use; and

(ix) design adaptability for future space use and expansion.

Okoye, et al., (2021) explain that the basic consideration of core housing is in the provision of simple minimal shelter for the households who otherwise may not access housing, such that this minimal shelter accommodates the basic functions that are usually performed in a house, namely: sitting, cooking, food storage, eating, sleeping and bathing. The notion of the minimal shelter catering for the basic functions is made possible by the provision of dual/multi-functional spaces enriched with flexibility in space use in place of the conventional structured and dedicated spaces for separate functions, the study further expounds. The achievement of provision of flexible spaces with the potential to achieve dual/multi-purpose usage is the attribute that makes the basic compact space provided work. The low-income households who are the main target group for core housing actually, and foremost, need just an affordable shelter which can cater for their basic housing needs to move into and then later upgrade this (Okoye, et al., 2021). Core housing is considered to satisfy the design functionality requirement of being fit for purpose in low-cost housing. Ibem, et al., (2015) observes that part of the success story of core housing in public housing provision is seen in terms of its functionality to provide good living conditions to the households. The study recognizes the ability of this housing system to generate designs that are flexible enough to respond to households' evolving needs as one of its advantages.

\section{Core Housing and Environmental Impact Reduction}

According to Mukhtar and Amirudin, 2016); the environmental quality and sustainability impact of the public housing projects is a very crucial consideration for measuring their performance. This is in order to discourage the practice of such developments contributing to and leading to detrimental environmental effects on the community. Shelter (2007) notes that 
the house and its environment impact on each other in a number of important areas such as: carbon emission from homes, the use of land for development, water supply and demand, sewerage and flood risk.

Ibem, et al., (2015) view environmentally sustainable housing as being free from environmental hazards, including chemical pollution. Furthermore, the study relates it to accessibility to amenities such as open spaces, parking lots for residents and quality of surroundings. Clement and Kayode (2012) consider environmentally efficient housing in terms of the quality of refuse disposal system, clean/conducive environment and availability of parking lots. Mukhtar and Amirudin (2016); also consider the environmental impact of the project as an essential measure of public housing product success. According to the study, the environmental quality and its sustainability to the needs of people of the area are very essential considerations. Public housing projects should therefore not lead to detrimental effects on the community or environment. All construction waste should be appropriately managed, and construction materials usage should be in accordance with the directives of relevant state protection agencies which are aimed at protecting the environment (Mukhtar \& Amirudin, 2016).

Ibem, et al., (2011) view environmentally sound housing from the angle of control of noise pollution level, control of air pollution, control of crime and anti-social behaviour, and promotion of communal activities. Ihuah, et al., (2014) suggest that an environmentally successful housing project is such that it provides for the reduction of the environmental and health impacts resulting from the project, buildings and the external built environment. Generally environmentally efficient housing is less expensive to operate, less vulnerable to increased energy costs, and provides for a higher quality of living environment.

From the preceding review, the following criteria are considered for the measurement of environmental efficiency in public housing within the context of this study:

(i) reduction of flood level;

(ii) reduction of noise pollution level;

(iii) reduction of air pollution level;

(iv) reduction of crime and anti-social behaviour;

(v) reduction of health impacts

(vi) quality of refuse disposal system;

(vii) cleanliness of environment

(viii) availability of communal (open) spaces; and

(ix) availability of parking lots.

The importance of environmental efficiency of public housing in ensuring sustenance and protection of the natural environment, while recognizing and mitigating the impact of the housing development on the environment, is a condition that core housing as a planned and orderly design system could fulfill. Core housing, being a low-cost housing practice and 
developed in such a way that its construction is simple and not complicated, has the advantage of easy usage of local building materials, such as mud blocks and bricks. Local building materials are known to be environmentally friendly. Core housing is observed to be organized to recognize the implication of the changes in the natural environment on the homes being built.

\section{Core Housing and Aesthetic Appeal}

Aesthetics appeal relates to the appearance of the built environment as concerns its beauty. According to Chipambwa (2017), within the design context aesthetic appeal is the immediate feelings evoked when experiencing a design product through the sensory system. Generally if public housing is designed to have an appealing appearance it will preserve respect to the occupants, and hence increase its acceptability (Mukhtar, et al., 2016). Therefore, the study opines that aesthetic appearance of the housing units is a principal measure of public housing product success. Ihuah, et al., (2014) equally maintains that aesthetic appearance is one of the important determinants of successful housing. Generally, it observes that if public housings are designed to have appealing appearance it will preserve respect to the occupants and this will increase the acceptability of the projects by the end users.

Neves, et al., (2014) shows the case of the Aranya community, started in the city of Indore, India, with the aim of creating core housing (incremental housing) for critical areas of the city. The findings indicate that the houses continued over time to evolve and grow physically and aesthetically, reflecting the users' needs, and capability of this house type to generate solutions. The neighbourhood became developed, providing an attractive environment for the residents and visitors, validating the ideals of core house design (Neves, et al., 2014).

However a challenge has been reported in the area of development control of this process. Beattie, et al., (2010) observe that, in the case of Dandora and Umoji, Nairobi, Kenya reported, once plots were occupied and the incremental development begun, the lack of government's support for the residents to plan and design their incremental stages led to a breakdown of urban form (aesthetics). This was because the Nairobi city council had no will or capacity to enforce building codes. While performing its goal of adaptation to the evolution of the family (growth or decrease of the number of family members), it is important for core house design to assure that it equally adapts to the site and urban context (Neves, et al., 2014).

Therefore, in order to ensure that there is an orderly physical development in the location and design of housing, the government usually intervenes in the housing process through preventive measures such as the enforcement of building bye laws, subdivision regulations and zoning ordinances, which serve as guides for future development. Such government interventions are mainly concerned in ensuring that the character, appearance and arrangement of buildings are maintained the way they should be. They also endeavour to make sure that the provision of facilities needed for the comfort, convenience, amenity and safety of the inhabitants of the settlements are well taken care of. It is the government that is in the right position and equipped to provide the necessary basic infrastructure, legal and regulatory framework, oversight and enforcements required in creating an enabling environment for urban housing development (Okpala, 1992). 
The study streamlines the following criteria for aesthetic efficiency;

(i) appearance of inside of building (initial unit);

(ii) appearance of outside of building (Initial unit);

(iii) appearance of inside of building (modified unit);

(iv) appearance of outside of building (modified unit);

(v) appearance of estate;

\section{Core Housing and Services Functionality}

Service efficiency explains the provision of adequate and functional components of building appliances and amenities such as: sanitary, plumbing, water supply and sewage disposal pipes or fixtures (Ilesanmi, 2010; Ibem, et al., 2013). Services provided through public housing projects according to Ibem, et al., (2013) include: the network of supportive services such as water supply, sanitary services and electrical services. Core house design takes the above into consideration by making provision for essential services in the design stage of this housing mechanism. However, more emphasis is given generally to the production of dwelling units than to accessibility of basic services and facilities for residents in public housing schemes.

From the above, this study designates the following criteria to measure core house design for services efficiency in public housing:

(i) efficiency of quality water supply;

(ii) efficiency of waste disposal system;

(iii) efficiency of electricity supply ;

(iv) nearness to medical support center (hospital);

(v) nearness to education center (primary school);

\section{CONCLUSION}

This study has shown that core housing as a housing delivery strategy contributes towards accelerating the rate of production of public housing stock. Assertions have also indicated that this housing strategy is capable of producing efficient public housing delivery in terms of design functionality, financial cost-saving, environmental impact relief, aesthetic appeal and services functionality. From the fore-going therefore Core Housing has been acknowledged as a housing delivery strategy that can perform efficient discharge of public housing, particularly in the interest of the low-income urban dwellers. The reason for unavailability of sufficient financial resources usually proffered as the government's excuse for abandonment of its housing responsibilities to citizens may not stand, given the observed merits of core housing strategy in this area. It therefore becomes necessary to further study this housing strategy in line with the various components of public housing efficiency in order to prove its efficacy for the much-needed improvement of public housing provision in Anambra State, Nigeria. 


\section{REFERENCES}

Abrams, C. (1964). Man's Struggle for Shelter in an Urbanizing World. Cambridge, M. I. T Press, 1-2, 174-181.

Ajanlekoko, J. (2001). Sustainable Housing Development in Nigeria: The Financial and Infrastructural Implications. International Conference on Spatial Information for Sustainable Development, (pp. 1-13,19). Nairobi, Kenya.

Atamewan, E. E., \& Olagunju, R. E. (2017). Incremental Construction for Sustainable LowIncome Housing Delivery in Developing Countries: A Case Study of Bayelsa State, Nigeria. Journal of Sustainable Architecture and Engineering, 20-38.

Balchin, P. R., Isaac, D., \& Chen, J. (2000). Urban Economics: A Global Perspective. New York: Palgrave.

Beattie, N., Mayer, C., \& Yildirim, A. (2010). Incremental Housing: Solutions to meet the global Urban housing challenge. United Nations World Forum.

Buckley, R., \& Kalarickal, J. (2005). Housing Policy in Developing Countries: Conjectures and Refutations. World Bank Research Observer, 20(2). Retrieved January 14, 2018, from http://ssrn.com/abstract=873741

Chivhanga, B., \& Muzenda, V. (2017). Issues in Art and Design. Chinhoyi University of Technology Publications, 62-75. Retrieved November, 2021.

Clement O. I., \& Kayode O., (2012). Public Housing Provision and User satisfaction in Ondo State, Nigeria, British Journal of Art and Sciences, ISSN:2046-9578, Vol. 8, No. 1, 2012, Pp. 103-111 http://www.bjounal.co.uk/B JASS.aspx

Goethert, R. (2010). Incremental Housing. a Pro-active Urban Strategy. Incremental Housing Bulletin.

Ibem, E. O., Aduwo, E. B., \& Ayo-Vaughan, E. K. (2015). Assessment of the Sustainability of Public Housing projects in Ogun State, Nigeria: A Post-Occupancy Evaluation Approach. Mediterranean Journal of Social Sciences, 6(452), 523-533. Retrieved July 2017.

Ibem, E. O., Anosike , M. N., \& Azuh, D. E. (2011). Challenges in Public Housing Provision in the Post-Independence Era in Nigeria. International Journal of Human Sciences, 8(2), 422-441. Retrieved September 8, 2016, from ISSN: 1303-5134.

Ibem, E. O., Opoko, A., Adeboye, A., \& Amole, D. (2013, June). Performance Evaluation of Residential Buildings in Public Housing Estates in Ogun State, Nigeria: Users Satisfaction Perspective. Frontiers of Architectural Research, 2(2), 178-190.

Ibimilua, A.F., \& Ibitoye, O.A. (2015). Housing Policy in Nigeria: An Overview, American International Journal of Contemporary Research, 5(2), 53-58. Retrieved July 2018.

Ihuah, P.W., Kakulu, I. I. \&Eaton, D. (2014). A review of Critical Project Management Success Factors (CPMSF) for sustainable social housing in Nigeria. International Journal of Built Sustainable Environment 2014 http://dx.doi.org/10.1016/j.ijsbe.2014.08.00. 1-10. Retrieved June 2018.

Kamau, P. K., \& Laszlo, A. (2002). Enhancing Housing Development and Ownership: Prospects for Individual Housing Development in Nairobi, Kenya. Systems Theories and A Prior Aspects or Perception, Amsterdam, pp. 47-74.

Kolli, H., \& Putta, V. (2014). Evaluation of public housing schemes: A case of greater Hyderabad Municipal corporation. Research Gate. Retrieved October 2014

Liu, A.M (1999). Residential Satisfaction in Housing Estates: Hong Kong Perspective. Journal of Automation in Construction, 8, (1), 11-524. 
Maly, E., \& Tamyo, K. (2012). An incrementally expandable core house for disaster reconstruction: Two cases in Yogyakarta, Indonesia, After the Central Java Earthquake. Memoirs of Graduate School of Engineering and Systems Informatics, 4, 1-7.

Mukhtar, M. M., \& Amirudin, R. (2016) The Success Criteria of Public Housing Projects in Nigeria. International journal of built environment and sustainability. Faculty of Built Environment, Universiti Teknologi Malaysia http://www.ijbes.utm.my IJBES 3(2)/2016, 102-110.

Napier, M. (2002). Core housing, enablement and urban poverty: The consolidation paths of households living in two South Saharan African settlements. Ph.D Thesis, University of Newcastle upon Tyne. Retrieved 2012, from http:/www.urbanlandmark.org.za

Neves, S.O., \& Amado, M.A., (2014). Incremental housing as a method of sustainable habitat, $30^{\text {th }}$ International Plea Conference CEPT University Ahmedabad, 1-7.

Okoye, N. B. C. D., Onyegiri, I. \& Okafor, M. (2021). Examining flexibility in space use in architectural design of public core housing schemes in Anambra State of Nigeria,. African Journal of Economics and Sustainable Development ISSN: 2689-5080, 4 (2), 39-85, DOI: 10.52589/AJESD-KHHYLSIW DOI URL: https://doi.org/10.52589/AJESD-KHHYLSIW www.abjournals.org. Retrieved November, 2021.

Okpala, D. (1992). Housing Production Systems and Technologies in Developing Countries, Habitat International, Vol. 16, Pergamon, London, p. 3.

Pandelaki, E., \& Shiozaki, Y. (2010). The core house concept and its implementation in Indonesia, past, present, future. International Journal for Housing Science, 34(44), 233 248. Retrieved 11 12, 2017, from www.housingscience.org/html/publications/pdf/34-42.pdf

Routio, P. (2007). Theories of Architecture.

Shelter (2007), Policy Briefings: Delivering Environmentally Sustainable Housing Growth, Shelter. The Housing and Homelessness Charity, 88 Old Street, EC1 V9 Hu, www.shelter.org.uk/policy briefings, 2007, 2-7. Retrieved July, 2018.

Ugonabo, C., \& Emoh, F. (2013). The major challenges to housing development and delivery in Anambra State of Nigeria. Civil and Environmental Research Journal, 3(4).

Waibel, M., Eckert, R., \& Bose, M. (2007). Housing for low-income groups in Ho Chi Minh city: between re-integration and fragmentation. Approaches to Adequate Urban Typologies and Spatial Strategies, 70-74.

World Bank (2018). Nigeria affordable housing project. Documentation/Integrated Safeguards Data Sheet (PID/ISDS).

Zukor, E. R. (1957). Origins of functionalist theory. New York: Columbia University Press. 